\title{
COMMONWEALTH TRADING PARTNERS
}

\section{Intra-Commonwealth trade}

As shown in Table 2, total exports of all Commonwealth countries to all destinations rose from $£ 18,171$ million in 1968 to $£ 20,559$ million in 1969 . These data are on a Customs clearance basis and are at national values, unlike the series shown in Table 1. They represent an increase amounting to 13 per cent for the year, which is close to the rate of expansion of world trade. Exports of Commonwealth countries to each other increased very substantially but at not quite the same rate, so that the intra-Commonwealth proportion of total Commonwealth exports declined slightly to 23 per cent. It will be seen that while British exports to other Commonwealth countries, and the exports of other Commonwealth countries to each other, did exceptionally well, exports of other Commonwealth countries to Britain moved up by a mere $£ 30$ million--a reflection of British economic policy, the import deposit scheme and high interest rates, which were ove 1 whelmingly directed towards improving the British balance of payments and the strength of sterling.

Substantially the same picture is presented by an examination of the statistics on the side of imports, although in this case, as Commonwealth imports from the world as a whole rose by only 8 per cent, the intra-Commonwealth proportion of this trade held steady-at least to the nearest percentage point.

More detailed statistics of intra-Commonwealth trade are set out in Appendix Tables II to IX. As already noted, the average proportion of Commonwealth exports going to other Commonwealth countries went down from 24 per cent in 1968 to 23 per cent in 1969; declines of a like order of magnitude affected most countries individually listed in Appendix Table III. In the case of Pakistan,

TABLE 2

INTRA-COMMONWEALTH TRADE $a$

f million

\begin{tabular}{|c|c|c|c|c|c|}
\hline & 1965 & 1966 & 1967 & 1968 & $1969 b$ \\
\hline 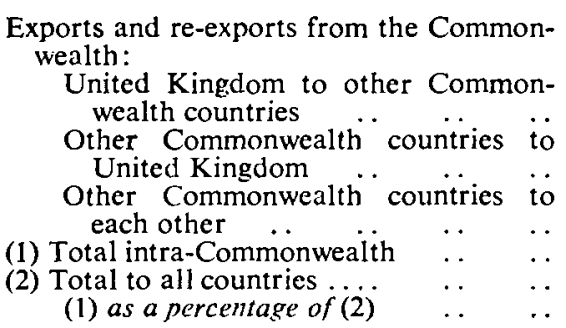 & $\begin{array}{r}1,435 \\
\\
1,188 \\
3,958 \\
12,713 \\
31\end{array}$ & $\begin{array}{r}1,431 \\
\\
1,173 \\
3,901 \\
13,785 \\
28\end{array}$ & $\begin{array}{r}1,359 \\
\\
1,241 \\
3,819 \\
14,177 \\
27\end{array}$ & $\begin{array}{r}1,394 \\
1,620 \\
1,429 \\
4,443 \\
18,171 \\
24\end{array}$ & $\begin{array}{r}1,543 \\
1,650 \\
1,633 \\
4,826 \\
20,559 \\
23\end{array}$ \\
\hline 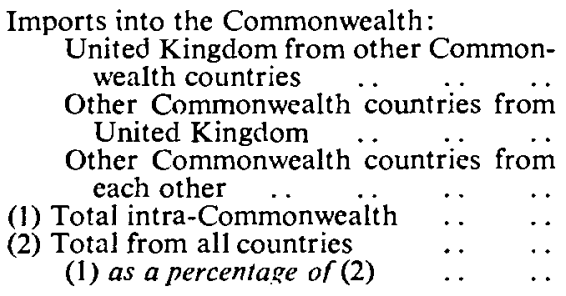 & $\begin{array}{r}1,673 \\
1,419 \\
1,118 \\
4,210 \\
14,585 \\
29\end{array}$ & $\begin{array}{r}1,590 \\
1,{ }^{3} 49 \\
1,144 \\
4,083 \\
15,140 \\
27\end{array}$ & $\begin{array}{r}1,574 \\
1,264 \\
1,218 \\
4,056 \\
16,307 \\
25\end{array}$ & $\begin{array}{r}1,790 \\
1,500 \\
1,397 \\
4,687 \\
20,088 \\
23\end{array}$ & $\begin{array}{r}1,874 \\
1,610 \\
1,526 \\
5,010 \\
21,605 \\
23\end{array}$ \\
\hline
\end{tabular}

$a$ Sum of individual country valuations.

$h$ Actuals, or annual rates based on latest data. 
however, the proportion of her exports going to other Commonwealth countries rose from 24 per cent to 37 per cent, reflecting a large increase in recorded shipments of raw jute to Singapore. Ghana also provided an exception to the general experience, the proportion of her exports going to other Commonwealth countries having risen year by year from 20 per cent in 1965 to 32 per cent in 1969. This is a reflection of the reorientation of trade from the earlier situation in which a larger proportion of exports had been earmarked to liquidate bilateral balances with Eastern Euıope. The proportion of the exports of East African countries going to other Commonwealth countries (including their own interterritorial trade) has shown no apparent tendency to decline since 1965 and indeed, in the case of Uganda, the proportion has increased from 41 per cent to 47 per cent, mainly due to shipments of coffee to Britain at higher world prices.

Against the general trend of recent years one or two countries, especially exporters of sugar and bananas from the Commonwealth Caribbean, show relatively stable proportions of exports going to Britain-as is not surprising in view of the regulated nature of this trade. In 1969, however, such was the effect of drought and shipping difficulties on supplies from the Jamaica Banana Board that the restrictive British quota (4,000 tons) on supplies from the dollar area had to be relaxed to make good a shortfall in Britain. It may be mentioned, also, that in the case of Jamaica the proportion of her imports derived from Commonwealth countries has not shown a parallel stability. The percentage shares of the Commonwealth in Jamaican imports fell year by year, from 43 per cent in 1965 to 33 per cent in 1969, as a result of the inexorable gains made in this market by the United States.

In May 1970 representatives of the governments of Barbados, Jamaica and St. Kitts-Nevis-Anguilla held discussions with the Canadian Government to discuss its decision to terminate the 1966 Ottawa Agreement, under which Caribbean sugar suppliers received a rebate on sugar shipments to Canada equal to the amount of import duty payable. This worked out to 29 cents per $100 \mathrm{lb}$ - the amount of the preferential rate of duty, compared with the m.f.n. rate of $\$ 1 \cdot 29 / 100 \mathrm{lb}$. The rebate system was a special concession given by Canada to aid Caribbean producers at a time when world sugar prices were extremely low. The rebate system was limited to 175,000 metric tons, but actual shipments (after filling Commonwealth Sugar Agreement and U.S. quotas) fell well below that figure from 1966 to 1969 owing to poor crops. The Canadian Government has proposed endowing an Agricultural Development Fund with \$EC 10 million as an acceptable substitute, in present conditions of higher prices and lower productivity in the sugar producing industries of the Commonwealth Caribbean, for the rebates which accrued directly to those industries.

Intra-Commonwealth trade as a whole continues to go up year by year, notwithstanding a number of adverse elements. Among the latter may be mentioned the intra-Commonwealth trade of Malaysia and Singapore, which reflects the virtual abolition of the Commonwealth preferences that were being granted by them and the effect this has had on their trade with Britain and the other Commonwealth countries concerned. Even in absolute terms the imports of Malaysia from Britain actually fell from 1965 to 1969 (Appendix Table VIII). Hong Kong has all along been for practical purposes a free port and the reorientation of her trade around the Pacific basin has not involved such a marked decline in the proportion of her imports obtained from Britain. The absolute value of trade both ways between Britain and India has shown a steep fall since 1965. In spite of these adverse elements, however, intra-Commonwealth exports advanced by almost $£ 400$ million in 1969 .

Appendix Table XI shows the proportion of British imports of particular commodities supplied by Commonwealth countries. Falls in proportions will 
be noted for meat, grain and tobacco-comparing 1969 with 1965 . The civil war had its effect on Nigerian shipments of petroleum oil, and palm nuts and kernels, all of which were predominantly produced in the former Eastern Region. Among manufactured articles it is particularly interesting to note that whereas Britain has been taking a steadily increasing proportion of its imports of wood manufactures from Commonwealth countries, the proportion of textiles from the Commonwealth has fallen notwithstanding the increasing value of imports of cotton textiles from Canada. In 1969 the British Government decided to introduce, with effect from 1st January 1972, a tariff on imports of cotton textiles from the Commonwealth Preference Area, with the existing quota system terminating on that date. The proposed rates were set at approximately $6 \frac{1}{2}$ per cent for yarn, 15 per cent for cloth and 17 per cent for garments, compared with m.f.n. rates of $7 \frac{1}{2}$ per cent, $17 \frac{1}{2}$ per cent and 20 per cent respectively, bringing the margin of Commonwealth preference on cotton textiles to the same level as on textiles of man-made fibres. Discussions will take place with Commonwealth countries at present having rights of duty free entry into the United Kingdom market for their cotton textiles. Such manufactures produced in EFTA (e.g. Portugal) and the Irish Republic would continue to enter dutyfree, but for those from (e.g.) Canada and developing Commonwealth countries the new preferential rates would apply. So far as the developing Commonwealth countries are concerned, it has been stated that with the possible exception of India, there was no reason to think that they would be able to export less over the proposed tariff than under a continuation of the present quota system; for India, it was said that Britain would be willing, in determining the level of aid to that country after 1972, to take into account, against the background of India's general aid requirements at the time, any adverse effects on her exports arising from the tariff.

Among the measures taken by some Commonwealth countries in the Caribbean and East Africa for expanding trade among themselves, thus contributing to the expansion of intra-Commonwealth trade, are the formation of CARIFTA and the East African Economic Community, of which mention may be made here. The Caribbean Free Trade Association (CARIFTA) completed its second year of integration activity in May 1970. This economic grouping links Guyana and the members of the former West Indies Federation, ${ }^{*}$ the eleven countries combined providing a market of 4.5 million people. To achieve its goals the CARIFTA Agreement provides for the removal of tariffs on trade among members over a five year period in the case of the more developed members and over ten years for the rest, with exceptions on a special Reserve List including some fruit and tobacco products, paints, radio and television sets, furniture, textiles, footwear, detergents and several other manufactures. Origin rules are designed to encourage the location of industry within the CARIFTA region, with imported raw materials generally entering duty-free. An Agricultural Marketing Protocol lists 21 commodities which may not be imported from sources outside the free trade area until all internal supplies have been exhausted.

The extent to which CARIFTA members are able to benefit from these arrangements depends largely on their individual economic structures and resources. Small size and a limited range of export products characterize most CARIFTA countries, all of which depend heavily on the sale of agricultural commodities. In Trinidad and Tobago, where industrial production contributes about half the domestic product, industrial activity is centred on oil refining, chemicals and fertilizers. Jamaica has the most diversified manufacturing base,

* Antigua, Barbados, Dominica, Grenada, Guyana, Jamaica, Montserrat, St. Kitts-NevisAnguilla, St. Lucia, St. Vincent, and Trinidad \& Tobago. 
with such industries as cement, oil refining, textiles, clothing and food processing. The inability of the CARIFTA countries in the past to satisfy more than a small part of each other's import needs is suggested by the low level of tradeabout 6 per cent of total exports-conducted within the region before the formation of the free trade area. It is too early, however to form an assessment of progress since the advent of the latter.

The East African Community (Kenya, Tanzania and Uganda) was inaugurated in December 1967 by the operative provisions of the Treaty for East African Co-operation. The underlying objective in establishing the Community was to strengthen and regulate the industrial, commercial and other relations of the member states so as to secure an accelerated and balanced growth of these economies. The formal establishment of a common market is one of the cornerstones of the Community arrangements. However, the nature of the common market provided for has been conditioned more by the desire for reasonable balance in intra-territorial trade and industrial development than by the wish to promote an increased volume of intra-territorial trade per se. Kenya has generally accounted for the greater part of the intra-territorial trade-to the extent of over 60 per cent. While the Treaty prohibits the imposition of internal tariffs on East African goods, it permits the imposition of transfer taxes on manufactures as part of the package of measures to stimulate industrial development in the less advanced countries (Tanzania and Uganda).

The life of the Community thus far has been relatively short, and it is not possible to assess the full impact of the Treaty's provisions. There exist some problems associated with the shortage of skilled manpower. Initial difficulties arising from the administration of transfer taxes, particularly the slow down caused in the movement of goods from Kenya to Tanzania and Uganda, were quickly overcome, and on the whole the transfer tax system seems to have proved less restrictive than the quantitative limitations which previously were in force.

\section{United States}

Despite an improvement in the U.S. merchandise trade balance late in 1969, the export surplus for the full year, at less than $\$ 0.7$ billion, was little changed from the unusually low 1968 surplus. The annual increases in both exports and imports were in the range of $\$ 2.8-2.9$ billion, to totals for the year of $\$ 36.5$ billion and $\$ 35.8$ billion respectively.

The year 1969 was marked in the United States by a process of review of the country's foreign economic policies. Emphasis was given to the concern reportedly felt at the high level of U.S. imports of textiles, which led to the belief that mandatory quotas might be imposed unless exporting countries, among them Hong Kong and Japan, did not impose their own "voluntary" restrictions on shipments of synthetic textiles to the United States. Protectionist sentiment also appeared to have gained strength, primarily from the widespread belief that U.S. exporters were being adversely affected by trade policies in certain other countries.

Among Commonwealth countries, exports by Canada to the United States, as shown in Table 3, went ahead strongly, in line with the trend established since the signing of the Auto-Pact. The U.S. now accounts for over 70 per cent of total Canadian exports. In March 1970, apparently under pressure from domestic oil producers, the U.S. Administration announced that the voluntary agreement with Canada on imports of crude and unfinished oil products into the United States was to be replaced by a stricter, temporary formal limitation. During the preceding few months, imports of Canadian oil had been running at up to 550,000 barrels a day, a fact which provoked considerable protests from 
U.S. producers whose domestic price for crude, at $\$ 3.30$ per barrel on the East Coast, was about 25 per cent higher than the Canadian level.

TABLE 3

EXPORTS FROM THE COMMONWEAL,TH TO THE UNITED STATES

f million

\begin{tabular}{|c|c|c|c|c|c|c|c|}
\hline & & & 1965 & 1966 & 1967 & 1968 & $1969 a$ \\
\hline 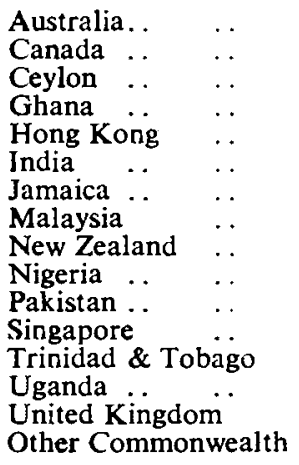 & $\begin{array}{l}. \\
\cdots \\
\cdots \\
\cdots \\
\cdots \\
\cdots \\
\cdots \\
\cdots \\
\cdots \\
\cdots \\
\cdots \\
\cdots \\
\cdots \\
\cdots\end{array}$ & 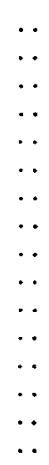 & $\begin{array}{r}114 \\
1,668 \\
11 \\
18 \\
113 \\
112 \\
29 \\
65 \\
43 \\
26 \\
17 \\
13 \\
46 \\
14 \\
521 \\
43\end{array}$ & $\begin{array}{r}142 \\
2,066 \\
10 \\
14 \\
134 \\
108 \\
31 \\
56 \\
62 \\
22 \\
25 \\
17 \\
57 \\
17 \\
652 \\
45\end{array}$ & $\begin{array}{r}139 \\
2,428 \\
10 \\
16 \\
165 \\
91 \\
33 \\
61 \\
56 \\
19 \\
27 \\
26 \\
68 \\
14 \\
639 \\
49\end{array}$ & $\begin{array}{r}202 \\
3,565 \\
10 \\
24 \\
249 \\
122 \\
36 \\
87 \\
79 \\
20 \\
41 \\
42 \\
90 \\
19 \\
910 \\
56\end{array}$ & $\begin{array}{r}235 \\
4,083 \\
11 \\
19 \\
319 \\
138 \\
41 \\
100 \\
79 \\
50 \\
32 \\
64 \\
90 \\
18 \\
906 \\
57\end{array}$ \\
\hline Total & .. & .. & 2,853 & 3,458 & 3,841 & 5,552 & 6,242 \\
\hline
\end{tabular}

a Actuals, or annual rates based on latest data.

TABLE 4

IMPORTS INTO THE COMMONWEALTH FROM THE UNITED STATES

E million

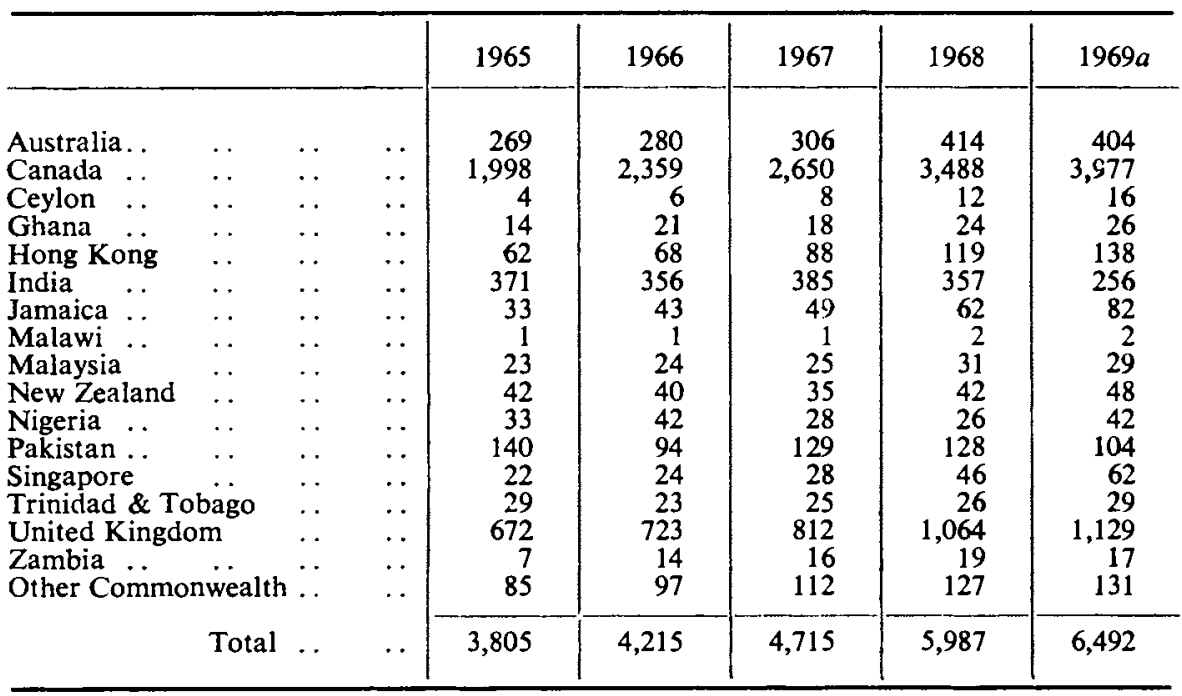

a Actuals, or annual rates based on latest data. 
After a phenomenal rise of exports to the U.S. in 1968 the value of British shipments more or less marked time in the year under review. However, exports from a number of other Commonwealth countries, notably Australia, Singapore, Nigeria and Jamaica, went ahead strongly-mostly in confirmation of longterm trends.

On the side of imports, as shown in Table 4, the major expansion in trade from the United States to Canada accounted for about $£ 490$ million out of the total increase of Commonwealth imports from the United States, amounting to about $£ 510$ million. British imports from the United States showed a very modest rise, in keeping with the restrictive trade policies temporarily enforced. A noteworthy decline in imports from the United States was recorded by India and Pakistan, largely because of much reduced imports of food aid following the dramatic improvement in the agricultural situation in these countries. The imports of Singapore, Hong Kong and Jamaica continued their strong secular growth in line with the expansion of trade in the opposite direction.

\section{European Economic Community}

In the final year of its "transitional" period, boom conditions prevailed throughout most of the European Economic Community, with exports expanding by 18 per cent. Imports went ahead strongly by about 22 per cent-a higher rate of expansion than was recorded during 1969 in any other major country or group.

The year was not without difficulties, however, especially in the field of monetary policy. Attention has already been drawn to the two major currency revaluations, downwards in the case of France and upwards in the case of the Federal Republic of Germany. Notwithstanding these developments, the European Economic Community finally moved into its "definitive" period on 1 January 1970. Some of its common policies were behind schedule, particularly in the agricultural sector where common marketing systems for products

TABLE 5

EXPORTS FROM THE COMMONWEALTH TO THE EUROPEAN ECONOMIC COMMUNITY

$£$ million

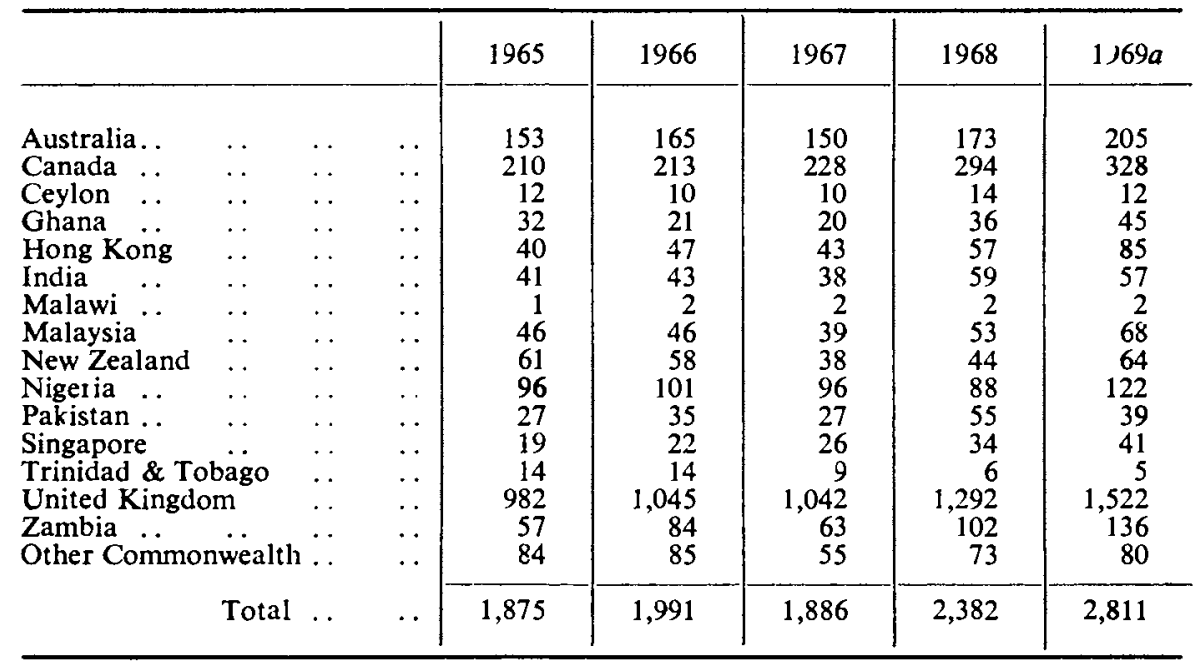

a Actuals, or annual rates based on latest data. 
like wine, tobacco, textile fibres, potatoes and sheepmeats had yet to enter into force. In particular, the new farm finance regulations agreed just before Christmas 1969 had not yet become operational, and on this hinged the whole of the package deal relating to the financing of Community institutions and progress with the applications for membership by Britain and a number of other countries. As indicated earlier, technical aspects of the agreement on wine, which had been holding things up, were finally settled in April 1970.

Moves toward closer economic relations with the European Economic Community were made during 1969 by a number of Commonwealth countries, like Malta and Mauritius, in addition to Britain. Progress towards definitive arrangements with such Commonwealth countries as have expressed interest in them now seems to hinge mainly upon developments in relation to the British application for membership. This applies particularly to Cyprus with its exports of fruit, vegetables and wine, to the Commonwealth sugar-producing countries, and to those African countries which might look for some form of association. The Yaounde Convention itself was renewed during the course of 1969 with provision for a slightly larger Development Fund and specific provision for trade promotion. Both the revised Yaounde Convention and the revised Arusha Convention (which latter does not provide for development finance or technical assistance) will run to 1975 , and negotiations for further renewal are to start well in advance of this date.

In January 1968, before the second plenary session of UNCTAD, the Indian Economic Mission at Brussels urged the Commission of the European Communities to make special efforts to assist the economic development of India by enlarging the opportunities for the export of her products to the Common Market. It suggested to the Commission that formal talks should begin immediately for working out a comprehensive commercial arrangement between India and the countries of the E.E.C. Although talks were then postponed because of the imminence of the second plenary session of UNCTAD, and

TABLE 6

IMPORTS INTO THE COMMONWEALTH FROM THE EUROPEAN ECONOMIC COMMUNITY

$f$ million

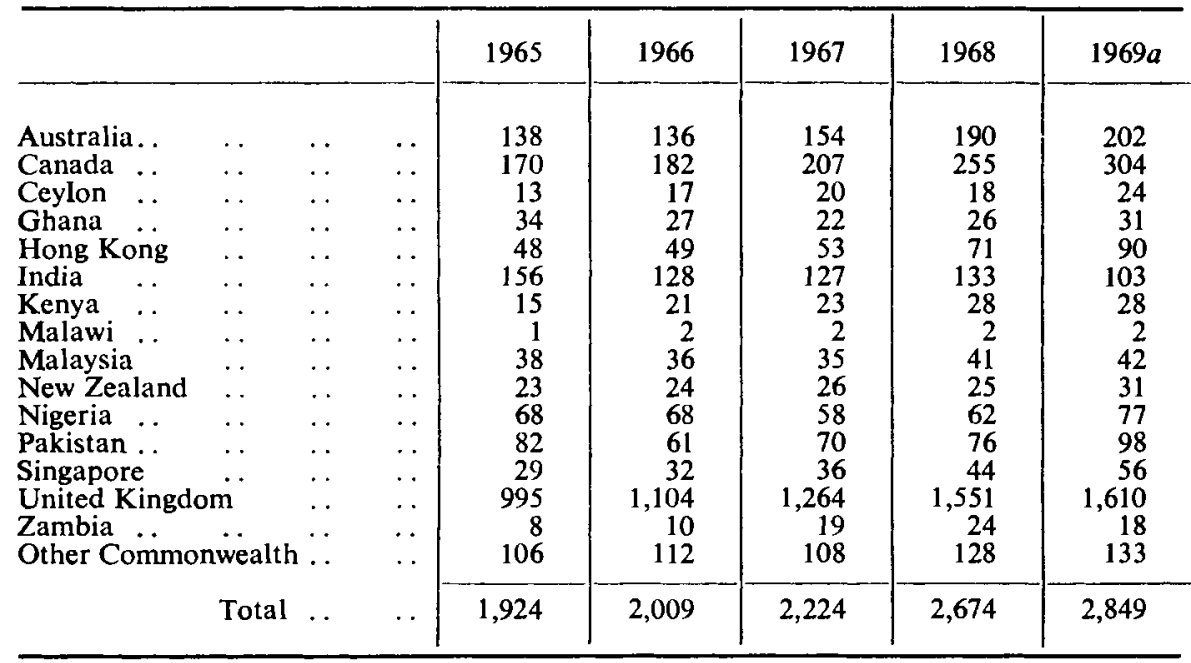

a Actuals, or annual rates based on latest data 
comprehensive arrangements now seem to await the first steps in the negotiations for British entry to the E.E.C., India has during the past few years secured notable concessions, almost all of which are applicable to other suppliers as well. There is total or partial suspension of the Common External Tariff on tea, spices (cardamom, coriander seeds and ginger), curry powder, mango chutney and bleached lac. In the cases of coffee, cashew nuts, pepper and castor oil, duty has been partially suspended. Other concessions applicable in the case of India include an annual duty-free quota for handloom silk and handloom cotton fabric to the extent of $\$ 1$ million each; duty-free entry for $\$ 500$ million of handicrafts annually; and elimination of duties on East India kips (leather). An agreement was signed in November 1969 providing for duty-free quotas in the E.E.C. on jute carpet backing for a 3 year period from January 1970. Pakistan has been holding parallel discussions with the European Commission. It was reported in the London press on 28 April 1970 that the E.E.C. has offered both India and Pakistan significant increases in their quotas for cotton textiles when the L.T.A. on cotton textiles is renegotiated later in the year. The L.T.A., which has already been renewed twice since its introduction in 1961, expires on 30 September, 1970, and discussions are proceeding in GATT about the future of the arrangement.

India, Pakistan and Ceylon are three countries that may expect to benefit from definitive overall trade arrangements with the E.E.C. in the context of British accession. Exports from these countries to the E.E.C. showed a disappointing reduction in 1969 as compared with 1968. Apart from these countries, and Trinidad and Tobago in the Caribbean, exports from Commonwealth countries as a whole to the E.E.C. did very well in 1969, as could have been expected in view of the boom conditions in that market. Out of the total expansion in sales amounting to $£ 430$ million, the jump in the value of British exports accounted for $£ 230$ million. Rises in imports from the E.E.C., as shown in Table 6, were also widespread, with Britain accounting for a smaller proportion of the overall increase.

\section{European Free Trade Association}

Total commodity imports of the eight countries combined (i.e. including the associate member Finland but excluding Iceland, which became the eighth full member only in March 1970), amounted to $£ 18,308$ million, and exports to $£ 15,923$ million, respectively 11 per cent and 15 per cent higher than in 1968 . Trade among the EFTA countries (measured by exports f.o.b.) rose by 17 per cent. Exports to the E.E.C. were buoyant, rising $18 \frac{1}{2}$ per cent, but imports from the Six were only 12 per cent higher, resulting in a further narrowing of EFTA's trade deficit with the E.E.C. Trade with the United States was comparatively stagnant after rapid growth in 1968; exports rose only $1 \frac{1}{2}$ per cent, while imports were up $7 \frac{1}{2}$ per cent. Exports to Eastern Europe and to the rest of the world increased by 11 per cent and 16 per cent respectively, while imports rose by 10 per cent and 6 per cent.

These figures are naturally influenced to a large extent by the trade of the dominant partner in the group, which is Britain. Indeed the 17 per cent increase in intra-EFTA exports in 1969, one of the highest increases in the past decade, was greatly influenced by the improved trading position of the United Kingdom. British sales to EFTA were 22 per cent higher than in 1968. Total Commonwealth exports to the continental members of EFTA went up by just short of $£ 200$ million, of which those from Britain alone accounted for $£ 170$ million.

In addition to the very large growth of British exports to continental EFTA, the exports from Hong Kong, although relatively small in absolute terms, represented a large proportionate increase. Sales of textiles and clothing from Hong Kong to the Scandinavian countries are very substantial. It is interesting 
to note that the growth of imports into Hong Kong from continental members of EFTA almost exactly matches the growth of trade in the other direction.

Apprehensions arose during 1969, among some of the continental members of EFTA, over the projected Nordek Treaty, involving the creation of a Scandinavian Customs Union. These plans did not, however, come to fruition partly because of some basic differences between the Scandinavian countries themselves, and partly as a result of the new situation created as a result of the expected opening of negotiations for accession to the E.E.C. on the part of Britain, the Irish Republic, Denmark and Norway.

TABLE 7

EXPORTS FROM THE COMMONWEALTH TO CONTINENTAL MEMBERS OF EFTA

\begin{tabular}{|c|c|c|c|c|c|c|c|}
\hline & & & 1965 & 1966 & 1967 & 1968 & $1969 a$ \\
\hline 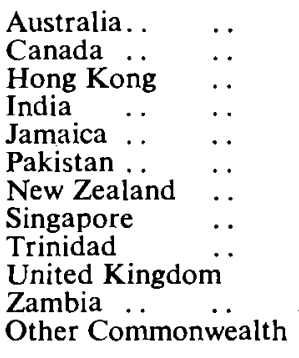 & $\begin{array}{l}. \\
\because \\
\because \\
\because \\
\because \\
\because \\
\because \\
\because \\
\cdots \\
\therefore \\
\cdots \\
\cdots\end{array}$ & $\begin{array}{l}\because \\
\because \\
\because \\
\because \\
\because \\
\because \\
\because \\
\because \\
\because \\
\because \\
\cdots\end{array}$ & $\begin{array}{r}11 \\
55 \\
13 \\
7 \\
7 \\
4 \\
4 \\
2 \\
10 \\
613 \\
8 \\
33\end{array}$ & $\begin{array}{r}10 \\
68 \\
15 \\
6 \\
7 \\
4 \\
4 \\
2 \\
11 \\
684 \\
14 \\
23\end{array}$ & $\begin{array}{r}12 \\
58 \\
22 \\
7 \\
8 \\
4 \\
4 \\
3 \\
12 \\
706 \\
14 \\
20\end{array}$ & $\begin{array}{r}11 \\
82 \\
25 \\
8 \\
11 \\
7 \\
3 \\
2 \\
18 \\
803 \\
18 \\
31\end{array}$ & $\begin{array}{r}14 \\
83 \\
38 \\
9 \\
14 \\
6 \\
4 \\
4 \\
12 \\
973 \\
23 \\
36\end{array}$ \\
\hline Total & .. & .. & 767 & 848 & 870 & 1,019 & 1,216 \\
\hline
\end{tabular}

a Actuals, or annual rates based on latest data.

TABLE 8

IMPORTS INTO THE COMMONWEALTH FROM CONTINENTAL MEMBERS OF EFTA

$£$ million

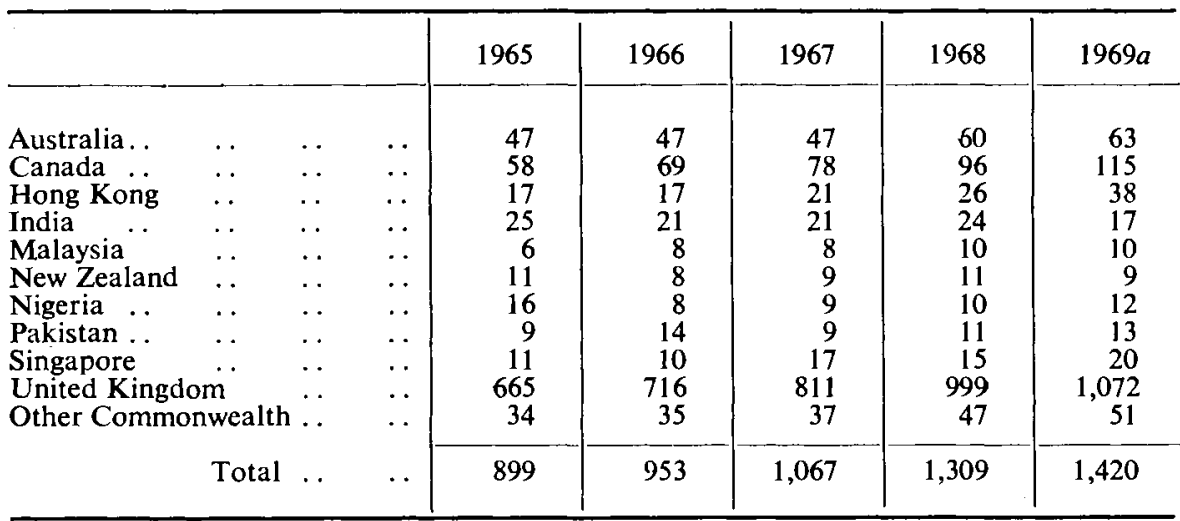

$a$ Actuals, or annual rates based on latest data. 
Japan

The rapid expansion of the Japanese economy has now continued unabated since the middle of 1965, thus making for the longest period of rapid and sustained expansion in the post-war era. Contrary to the country's experience in previous periods of rapid growth its balance of payments situation suffered no adverse effects. Real gross national product went up by about 13 per cent in 1969 after a similar rise in 1968 ; yet the trade surplus reached $\$ 3.7$ billion, compared with $\$ 2.5$ billion in the previous year, and the current account surplus widened from $\$ 1 \cdot 1$ billion to $\$ 2 \cdot 2$ billion.

TABLE 9

EXPORTS FROM THE COMMONWEALTH TO JAPAN

f million

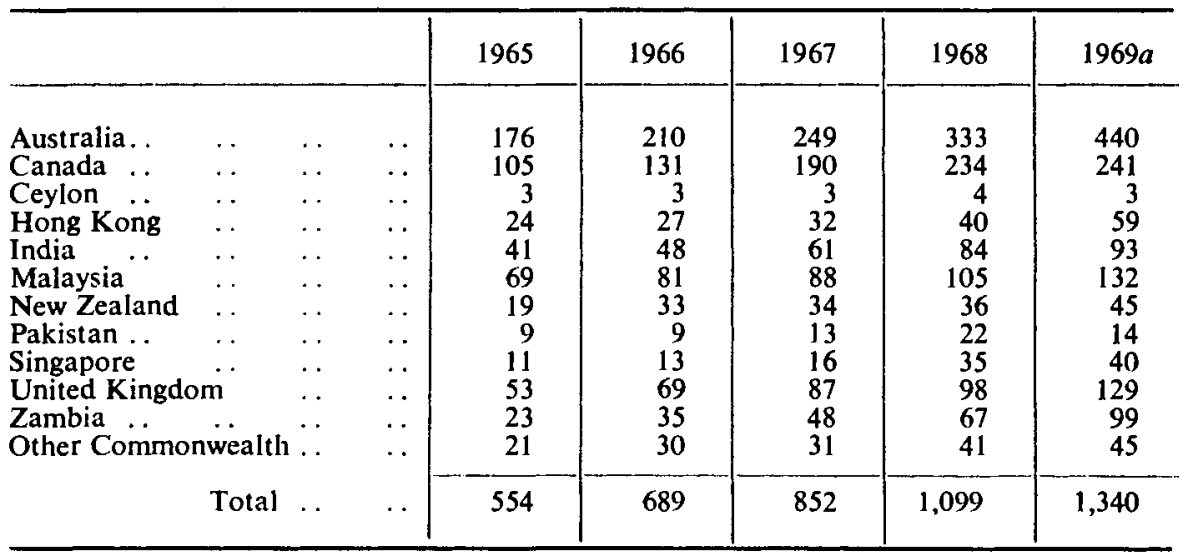

a Actuals, or annual rates based on latest data.

Japanese official agencies and businessmen continued during 1969 to express great caution about future prospects, as pressure built up for action either to revalue the yen or to introduce greater liberalisation of both trade and capital movements. During 1969 there was an easing of foreign exchange regulations, and tariff protection on large motorcars was cut. Trade figures for the year showed a slower growth of exports to the United States, largely offset by more rapid expansion of shipments to Europe. Sales abroad of motor vehicles, television sets, radio receiving sets and tape-recorders, all rose by well over a third. Overall, exports rose by 23 per cent and imports by 17 per cent in 1969 . With a surplus in the overall balance of payments, foreign exchange reserves rose during the year from $\$ 2,891$ million to $\$ 3,496$ million.

Total exports from the Commonwealth to Japan rose by 22 per cent in 1969 to $£ 1,340$ million-well in excess of total Commonwealth imports from Japan, and well in excess of the growth of Japanese imports from the world as a whole. Because Japan is far from self-sufficient in a number of products, notably raw materials, the pace of domestic economic expansion will greatly influence her future importation of these products, for the supply of which several Commonwealth countries are very well placed. Canada, Australia, India, Malaysia, Singapore and Zambia are among the major suppliers of raw materials for the burgeoning Japanese economy. And even in the case of Hong Kong, which has practically no raw materials for export, such has been the improvement in productivity and international competitiveness of its industry that exports to Japan are taking place on a growing scale even in such items as had previously given Japan world leadership. 
TABLE 10

IMPORTS INTO THE COMMONWEALTH FROM JAPAN

$£$ million

\begin{tabular}{|c|c|c|c|c|c|c|}
\hline & & 1965 & 1966 & 1967 & 1968 & $1969 a$ \\
\hline 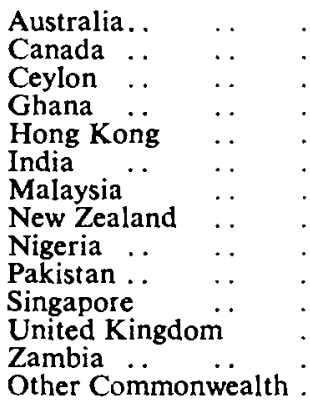 & 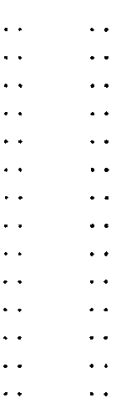 & $\begin{array}{r}117 \\
76 \\
8 \\
7 \\
97 \\
61 \\
40 \\
22 \\
26 \\
37 \\
49 \\
78 \\
4 \\
49\end{array}$ & $\begin{array}{r}104 \\
84 \\
9 \\
7 \\
115 \\
48 \\
47 \\
21 \\
14 \\
28 \\
54 \\
77 \\
4 \\
40\end{array}$ & $\begin{array}{r}127 \\
101 \\
7 \\
7 \\
125 \\
47 \\
50 \\
22 \\
19 \\
34 \\
64 \\
91 \\
9 \\
44\end{array}$ & $\begin{array}{r}173 \\
139 \\
8 \\
7 \\
787 \\
66 \\
66 \\
28 \\
8 \\
47 \\
94 \\
115 \\
11 \\
59\end{array}$ & $\begin{array}{r}206 \\
191 \\
13 \\
8 \\
240 \\
36 \\
71 \\
33 \\
8 \\
48 \\
122 \\
104 \\
14 \\
63\end{array}$ \\
\hline Total . & $\ldots$ & 671 & 652 & 747 & 1,008 & 1,157 \\
\hline
\end{tabular}

a Actuals, or annual rates based on latest data.

The export of Indian iron ore to Japan entered into a more promising phase in 1969, marked by the signing of two agreements between the State-owned Corporations in India and the Japanese steel industry. One of these provides for the purchase of 14.7 million metric tons of lump iron ore by Japanese steel mills over a 5 year period beginning January 1971. Under the other agreement, 46 million metric tons of iron ore should be exported from India to Japan over 8 years from April 1970. Over a quarter of the world's proven reserves of iron ore are located in India, but the duration of the Indian contracts with Japanese mills do not match those of Australian producers.

With regard to Commonwealth imports from Japan, the increases recorded by Hong Kong, Singapore, Malaysia, Australia, and Canada, not only in 1969 but also over the preceding years, are particularly noteworthy. In view of the reciprocal trading interests, geographical location and the known competitiveness of Japanese industry no special explanation is called for. Imports into a number of Commonwealth African countries from Japan have been under varying measures of restraint. Zambia, which runs a large trade surplus with Japan through its export of copper, is an exception to the foregoing and its imports from Japan are on a rising trend, notwithstanding its own efforts at industrial diversification.

\section{Eastern Europe}

According to the Economic Commission for Europe, acceleration of the growth of the foreign trade of Eastern Europe began in 1967, after a setback in the mid-1960s, and continued in 1969. Increasing dependence on foreign trade has taken place at the same time as the growth of net material product has slowed down, so that the ratio of growth in trade to growth in net material product rose from 1.0 in 1967 to 1.2 in the following year and 1.6 in 1969. The intra-trade of the region increased in 1969 at a rather slower pace than trade with the rest of the world: trade with Western Europe and with developing countries expanded faster than the total turnover of the region. 
TABLE 11

EXPORTS FROM THE COMMONWEALTH TO EASTERN EUROPE

\begin{tabular}{|c|c|c|c|c|c|c|}
\hline & & 1965 & 1966 & 1967 & 1968 & $1969 a$ \\
\hline Australia. . & . & 43 & 25 & 23 & 27 & 33 \\
\hline Canada ... & .. & 101 & 131 & 60 & 53 & 12 \\
\hline Ceylon .. & .. & 13 & 11 & 8 & 11 & 12 \\
\hline Ghana.. & .. & 18 & 16 & 13 & 8 & 6 \\
\hline India : & . & 99 & 99 & 95 & 133 & 146 \\
\hline Malaysia & & 32 & 34 & 27 & 37 & 49 \\
\hline New Zealand & .. & 3 & 8 & 4 & 7 & 8 \\
\hline Pakistan .. & . & 6 & 13 & 17 & 23 & 30 \\
\hline Singapore & . & 20 & 17 & 14 & 20 & 24 \\
\hline United Kingdom & .. & 117 & 151 & 174 & 229 & 231 \\
\hline Zambia $\ldots \quad \ldots$ & . & 4 & 5 & 3 & 3 & 4 \\
\hline Other Commonwealth $b$ & $\cdots$ & 9 & 11 & 9 & 25 & 23 \\
\hline Total . & . & 465 & 521 & 447 & 576 & 578 \\
\hline
\end{tabular}

a Actuals, or annual rates based on latest data.

$b$ Including estimates for Nigeria.

TABLE 12

IMPORTS INTO THE COMMONWEALTH FROM EASTERN EUROPE

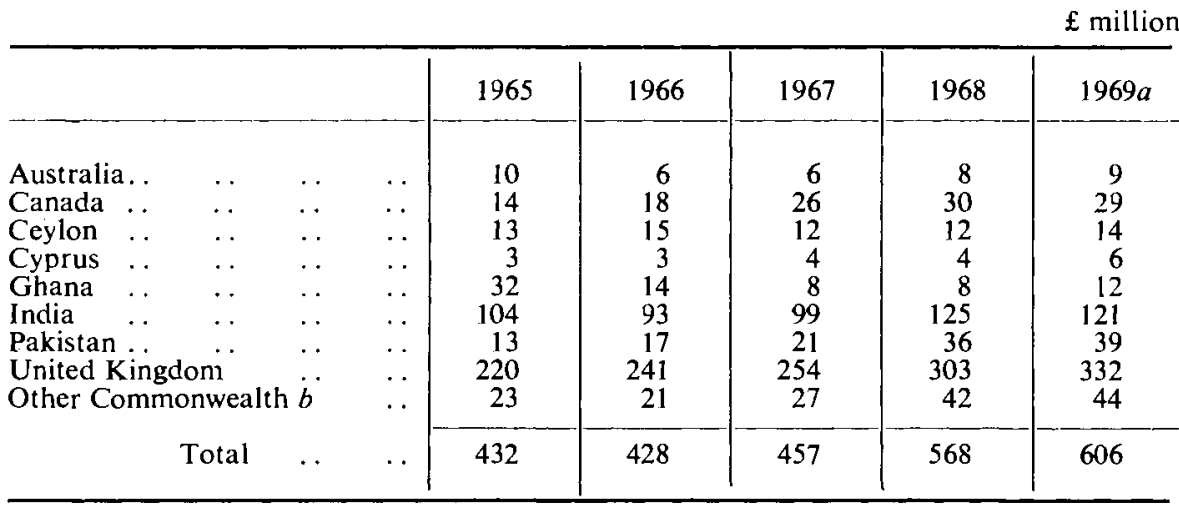

a Actuals, or annual rates based on latest data.

$b$ Including estimates for Nigeria.

As shown in Table 11, aggregate exports from Commonwealth countries to Eastern Europe showed practically no change comparing 1969 with 1968, the general increases in exports from individual Commonwealth countries being offset by another substantial fall in Canadian exports-chiefly of wheat to the Soviet Union. The latter country's three year contract to buy 336 million bushels of Canadian wheat by July 31, 1969, was under-fulfilled on that date by 135 million bushels, representing about $\$ 300$ million in sales for Canadian farmers. A new agreement between the Canadian Wheat Board and the Soviet buying agency at the turn of the year covered the balance of the 1966 contract, providing for shipment (including 260,000 tons of flour to be shipped to Cuba) before the end of 1970. 
Apart from the exceptional case of Canada, there were general rises in Commonwealth exports to Eastern Europe in 1969, especially from the area of the Indian Ocean and Australasia. British exports to Eastern Europe, however, increased by a good deal less than imports therefrom. The imbalance of the trade of Britain with Eastern Europe has been noted on many occasions, but due allowance has to be made for the difference in valuation between exports (f.o.b.) and imports (c.i.f.), as well as the nature of the British re-export trade in diamonds supplied by the Soviet Union. At the end of April 1970 it was announced by the U.K. Board of Trade that restrictions would be removed on imports of a further range of goods from Eastern Europe. The principal items affected were canned salmon, toys and games, man-made fibres and filament yarns, typewriters and parts, motor and pedal bicycles and miscellaneous textiles already liberalised from Japan. As a result of these changes, less than 10 per cent of Britain's imports from Eastern Europe will in future be subject to bilateral quotas. The list of liberalised goods was last enlarged in 1966 although quota increases had continued to be given in the annual trade negotiations.

\section{China}

In 1969 Britain emerged as the leading Commonwealth exporter to China with the value of shipments exceeding $£ 50$ million for the first time in the trade between the two countries. A major factor in Britain's success in the Chinese market was the heavy volume of metals purchasing done by China early in the year at the London Metal Exchange, although China also made extensive metal purchases in Europe. As the year wore on there was some switch in Chinese buying interest from metals to machinery.

Australian exports to China in 1969 , valued at $£ 50$ million, were not out of line with the general trend of Australia's experience in this market, which tends to fluctuate widely according to the extent of supply of whent. In December 1969 it was announced by the Chairman of the Australian Wheat Board that a new contract had been signed with China covering the sale of $2 \cdot 2$ million tons of wheat valued at $£ 46 \cdot 6$ million. China had been buying Australian wheat for about six years and for the past four years had been the biggest single customer, taking about a third of the export crop. The contract carried the usual provisions as to terms and was for shipment in December 1969, when the current contract would have been completed to October 1970 inclusive.

TABLE 13

EXPORTS FROM THE COMMONWEALTH TO CHINA

$£$ million

\begin{tabular}{|c|c|c|c|c|c|c|c|}
\hline & & & 1965 & 1966 & 1967 & 1968 & $1969 a$ \\
\hline $\begin{array}{ll}\text { Australia .. } & \ldots \\
\text { Canada .. } & \ldots \\
\text { Ceylon ... } & \ldots \\
\text { Hong Kong } & \ldots \\
\text { Malaysia } & \ldots \\
\text { Pakistan .. } & \ldots \\
\text { Singapore } & \ldots \\
\text { United Kingdom } \\
\text { Other Commonwealth }\end{array}$ & $\begin{array}{l}\cdots \\
\cdots \\
\cdots \\
\cdots \\
\cdots \\
\cdots \\
\cdots \\
\cdots\end{array}$ & $\begin{array}{l}\cdots \\
\cdots \\
\cdots \\
\cdots \\
\cdots \\
\cdots \\
\cdots\end{array}$ & $\begin{array}{r}59 \\
35 \\
13 \\
4 \\
15 \\
3 \\
26 \\
16\end{array}$ & $\begin{array}{r}30 \\
61 \\
13 \\
4 \\
11 \\
16 \\
34 \\
11\end{array}$ & $\begin{array}{r}68 \\
30 \\
12 \\
3 \\
2 \\
12 \\
11 \\
39 \\
13\end{array}$ & $\begin{array}{r}37 \\
63 \\
14 \\
3 \\
10 \\
11 \\
11 \\
29 \\
13\end{array}$ & $\begin{array}{r}50 \\
47 \\
16 \\
3 \\
20 \\
12 \\
24 \\
54 \\
12\end{array}$ \\
\hline Total & . & $\ldots$ & 171 & 180 & 190 & 191 & 238 \\
\hline
\end{tabular}

a Actuals, or annual rates based on latest data. 
TABLE 14

IMPORTS INTO THE COMMONWEALTH FROM CHINA

f nillion

\begin{tabular}{|c|c|c|c|c|c|c|c|}
\hline & & & 1965 & 1966 & 1967 & 1968 & $1969 a$ \\
\hline 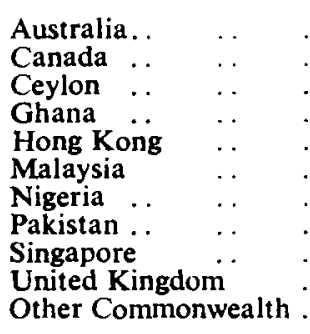 & $\begin{array}{l}. \\
\therefore \\
\therefore \\
\therefore \\
\therefore \\
\cdots \\
\cdots \\
\therefore \\
\therefore \\
\cdots\end{array}$ & $\begin{array}{l}\cdots \\
\cdots \\
\cdots \\
\cdots \\
\cdots \\
\cdots \\
\cdots \\
\cdots \\
\cdots \\
\cdots\end{array}$ & $\begin{array}{r}9 \\
5 \\
9 \\
5 \\
145 \\
27 \\
6 \\
7 \\
26 \\
27 \\
7\end{array}$ & $\begin{array}{r}9 \\
7 \\
16 \\
3 \\
173 \\
28 \\
4 \\
10 \\
32 \\
34 \\
12\end{array}$ & $\begin{array}{r}10 \\
8 \\
14 \\
143 \\
31 \\
12 \\
45 \\
30 \\
10\end{array}$ & $\begin{array}{r}12 \\
9 \\
17 \\
1 \\
167 \\
33 \\
12 \\
163 \\
34 \\
16\end{array}$ & $\begin{array}{r}14 \\
11 \\
20 \\
2 \\
186 \\
31 \\
12 \\
58 \\
38 \\
13\end{array}$ \\
\hline Total & $\ldots$ & . & 273 & 328 & 303 & 364 & 385 \\
\hline
\end{tabular}

$a$ Actuals, or annual rates based on latest data.

Canadian sales to China in 1969 , although still very large, showed a substantial drop on the record figure of the preceding year. As in the case of Australia, grains are the main component of this trade. In September 1969 the Canadian Wheat Board announced the sale of $2 \cdot 2$ million tons of wheat to China (the same size as the Australian contract) with delivery to begin that month and spread over a period of a year.

Among the other Commonwealth countries having a substantial and growing export trade with China, Malaysia and Singapore are outstanding - the chief commodity involved being rubber. These countries, however, imported less from China in 1969, as shown in Table 14, which incidentally points to the resumption of imports from China by Ghana, and the continuing absence of trade relations between Nigeria and China. 
TABLE 15

TRADE OF THE COMMONWEALTH WITH MAIN TRADING AREAS

\begin{tabular}{|c|c|c|c|c|c|c|c|}
\hline & & & 1965 & 1966 & 1967 & 1968 & $1969 a$ \\
\hline $\begin{array}{l}\text { Exports to: } \\
\text { Commonwealth } \\
\text { United States } \\
\text { E.E.C. } \\
\text { EFTA (Continental) } \\
\text { Japan } \\
\text { Eastern Europe } \\
\text { China .. ... } \\
\text { Other countries }\end{array}$ & $\begin{array}{l}\ldots \\
\cdots \\
\cdots \\
\ldots \\
\cdots \\
\cdots\end{array}$ & $\begin{array}{l}. \\
. \\
\because \\
\because \\
\therefore \\
\therefore \\
\therefore \\
.\end{array}$ & $\begin{array}{r}3,958 \\
2,853 \\
1,875 \\
767 \\
554 \\
465 \\
171 \\
2,070\end{array}$ & $\begin{array}{c}\text { f million } \\
3,901 \\
3,458 \\
1,991 \\
848 \\
689 \\
521 \\
180 \\
2,197\end{array}$ & $\begin{array}{r}3,819 \\
3,841 \\
1,886 \\
870 \\
852 \\
447 \\
190 \\
2,272\end{array}$ & $\begin{array}{r}4,443 \\
5,552 \\
2,382 \\
1,019 \\
1,099 \\
576 \\
191 \\
2,909\end{array}$ & $\begin{array}{r}4,826 \\
6,242 \\
2,811 \\
1,216 \\
1,340 \\
578 \\
238 \\
3,308\end{array}$ \\
\hline Total & .. & $\ldots$ & 12,713 & 13,785 & 14,177 & 18,171 & 20,559 \\
\hline $\begin{array}{l}\text { Imports from: } \\
\text { Commonwealth } \\
\text { United States } \\
\text { E.E.C. } \\
\text { EFTA (Continental) } \\
\text { Japan .. } \\
\text { Eastern Europe } \\
\text { China .. .. } \\
\text { Other countries }\end{array}$ & $\begin{array}{l}\cdots \\
\cdots \\
\cdots \\
\cdots \\
\cdots \\
\cdots\end{array}$ & $\begin{array}{l}. \\
. \\
\because \\
\because \\
\because \\
\therefore \\
\therefore\end{array}$ & $\begin{array}{r}4,210 \\
3,805 \\
1,924 \\
899 \\
671 \\
432 \\
273 \\
2,371\end{array}$ & $\begin{array}{r}4,083 \\
4,215 \\
2,009 \\
953 \\
652 \\
428 \\
328 \\
2,472\end{array}$ & $\begin{array}{r}4,056 \\
4,715 \\
2,224 \\
1,067 \\
747 \\
457 \\
303 \\
2,738\end{array}$ & $\begin{array}{r}4,687 \\
5,987 \\
2,674 \\
1,309 \\
1,008 \\
568 \\
364 \\
3,491\end{array}$ & $\begin{array}{r}5,010 \\
6,492 \\
2,849 \\
1,420 \\
1,157 \\
606 \\
385 \\
3,686\end{array}$ \\
\hline Total & .. & . & 14,585 & 15,140 & 16,307 & 20,088 & 21,605 \\
\hline $\begin{array}{l}\text { Exports to: } \\
\text { Commonwealth } \\
\text { United States } \\
\text { E.E.C. } \\
\text { EFTA (Continental) } \\
\text { Japan . . } \\
\text { Eastern Europe } \\
\text { China .. . } \\
\text { Other countries }\end{array}$ & $\begin{array}{l}\cdots \\
\cdots \\
\cdots \\
\cdots \\
\cdots \\
\cdots\end{array}$ & $\begin{array}{l}. \\
\because \\
\cdots \\
\cdots \\
\cdots \\
\cdots \\
.\end{array}$ & $\begin{array}{l}\text { Percen } \\
31 \\
22 \\
15 \\
6 \\
4 \\
4 \\
1 \\
17\end{array}$ & $\begin{array}{c}\text { ge of total } \\
28 \\
25 \\
14 \\
6 \\
5 \\
4 \\
1 \\
17\end{array}$ & $\begin{array}{r}\text { ade } \\
27 \\
27 \\
13 \\
6 \\
6 \\
3 \\
1 \\
17\end{array}$ & $\begin{array}{r}24 \\
31 \\
13 \\
6 \\
6 \\
3 \\
1 \\
16\end{array}$ & $\begin{array}{r}23 \\
30 \\
14 \\
6 \\
7 \\
3 \\
1 \\
16\end{array}$ \\
\hline Total & $\cdots$ & . & 100 & 100 & 100 & 100 & 100 \\
\hline $\begin{array}{l}\text { Imports from: } \\
\text { Commonwealth } \\
\text { United States } \\
\text { E.E.C. } \\
\text { EFTA (Continental) } \\
\text { Japan } . . \\
\text { Eastern Europe } \\
\text { China .. . } \\
\text { Other countries }\end{array}$ & $\begin{array}{l}\because \\
\cdots \\
\cdots \\
\therefore \\
.\end{array}$ & $\begin{array}{l}. \\
\because \\
\because \\
. \\
\therefore \\
\therefore \\
.\end{array}$ & $\begin{array}{r}29 \\
25 \\
13 \\
6 \\
5 \\
3 \\
2 \\
16\end{array}$ & $\begin{array}{r}27 \\
28 \\
13 \\
6 \\
4 \\
3 \\
2 \\
17\end{array}$ & $\begin{array}{r}25 \\
29 \\
14 \\
7 \\
5 \\
3 \\
2 \\
15\end{array}$ & $\begin{array}{r}23 \\
30 \\
13 \\
7 \\
5 \\
3 \\
2 \\
17\end{array}$ & $\begin{array}{r}23 \\
30 \\
13 \\
7 \\
5 \\
3 \\
2 \\
17\end{array}$ \\
\hline Total & .. & .. & 100 & 100 & 100 & 100 & 100 \\
\hline
\end{tabular}

a Actuals, or tonual rates based on the latest data. 